\title{
ROSAMICIN*: IN VITRO ACTIVITY COMPARISON WITH ERYTHROMYCIN AND OTHER ANTIBIOTICS AGAINST CLINICAL ISOLATES FROM THE GENITO-URINARY TRACT AND NEISSERIA MENINGITIDIS
}

\author{
P. C. FuCHS** \\ Department of Pathology, St. Vincent Hospital \& Medical Center, Portland, Oregon 97225 U.S.A. \\ C. THORNSBERry \\ Antimicrobics Investigations Section, Center for Disease Control, Atlanta, Georgia 30333 U.S.A.
}

A. L. BARRY

Clinical Microbiology Laboratories, University of California (Davis), Sacramento Medical Center, Sacramento, California 97817 U.S.A.

R. N. JONES

Department of Pathology, Kaiser Foundation Laboratory, Clackamas, Oregon 97015 U.S.A.

T. L. Gavan

Department of Microbiology, The Cleveland Clinic Foundation, Cleveland, Ohio 44106 U.S.A.

E. H. Gerlach

Microbiology Laboratory, St. Francis Hospital, Wichita, Kansas 67214 U.S.A.

H. M. SOMMERS

Department of Pathology, Northwestern Memorial Hospital, Chicago, Illinois 60611 U.S.A.

(Received for publication July 4, 1979)

\begin{abstract}
Rosamicin in vitro activity was compared with that of erythromycin and other antimicrobics against clinical urinary tract isolates, genital pathogens and Neisseria meningitidis. Although the susceptibility or resistance to the two macrolides almost perfectly paralleled each other, the activity of rosamicin was greater than that of erythromycin against most species tested, including the Enterobacteriaceae, non-fermentative Gram-negative bacilli, N. gonorrhoeae, $N$. meningitidis and Haemophilus vaginalis. No differences were seen between the two against Staphylococcus aureus, and erythromycin was superior against Streptococcus pyogenes. Significant increased activity of both drugs was observed against Gram-negative bacilli upon alkalinization of the media. The differences between bacteriostatic and bactericidal levels of rosamicin were greater against Gram-negative bacilli than Gram-positive cocci. The effect of inoculum size on increasing the minimal inhibitory concentrations (MIC) of rosamicin was significant above inocula of $10^{5}$ bacteria/ml, but not below this level. Dilution-zone size regression analyses showed good correlation with rosamicin, yielding suggested susceptibility breakpoints of $1 \mu \mathrm{g} / \mathrm{ml}$ and $24 \mathrm{~mm}$ zone of inhibition with $15-\mu \mathrm{g}$ discs. The erythromycin regression analysis data in this study suggest that the NCCLS zone size criteria may be too low. The exquisite susceptibility of genital pathogens to rosamicin plus the pharmacologic concentration of rosamicin in prostate, urethra and vaginal secretions renders this drug worthy of further investigation for possible use in genital tract infections.
\end{abstract}

The investigational macrolide rosamicin has an increased antimicrobic spectrum compared to erythromycin against most aerobic and anaerobic Gram-positive and Gram-negative bacteria, as well as chlamydiae ${ }^{1 \sim 8)}$. Animal and human pharmacokinetic studies have demonstrated that rosamicin

* Synonym: rosaramicin.

** Requests for reprints should be addressed to P. C. Fuchs, M. D., St. Vincent Hospital \& Medical Center, Portland, Oregon 97225, U.S.A. 
attains about one-half the serum levels reached by comparable doses of erythromycin, but it is concentrated in urethral, vaginal and prostatic tissue and secretions $\mathbf{s}^{9,10)}$. Thus, the antimicrobic spectrum and pharmacology of rosamicin suggest its application to the therapy of genito-urinary tract infections. The following study was designed to: (1) Determine the minimal inhibitory concentration (MIC's) of rosamicin, erythromycin and ampicillin for clinical isolates of bacterial urinary tract pathogens at six institutions; (2) Determine the susceptibility of genital tract bacterial pathogens to rosamicin, erythromycin and other antimicrobics; (3) Assess the effect of $\mathrm{pH}$ and inoculum size on the MIC's of rosamicin and erythromycin against clinical bacterial isolates; (4) Determine the bactericidal concentrations of rosamicin and erythromycin against select bacterial isolates; and (5) Perform regression line analyses for rosamicin with $15-\mu \mathrm{g}$ discs.

\section{Methods and Materials}

Antimicrobics

Rosamicin was supplied in powdered form and in $15-\mu \mathrm{g}$ discs by Schering Corporation, Bloomfield, NJ, and erythromycin estolate by Eli Lilly \& Co., Indianapolis, Ind. The antimicrobics were dissolved in MUELLER-HiNTON broth or agar in concentrations of $64 \mu \mathrm{g} / \mathrm{ml}$ with serial twofold dilutions to $0.06 \mu \mathrm{g} / \mathrm{ml}$. The various broth dilutions of each drug were dispensed in $0.1 \mathrm{ml}$ quantities in the wells of microdilution trays (Micro-Media Systems, San Jose, California or Cook Laboratory Products, Alexandria, Virginia). The agar dilutions of each drug were dispensed in $20 \mathrm{ml}$ quantities in 90-mm Petri plates. The antimicrobic containing broth was stored at $-20^{\circ} \mathrm{C}$ until placed into use, and the agar plates were stored at $4^{\circ} \mathrm{C}$.

\section{Bacterial Isolates}

In the study of the comparative efficacy of rosamicin against urinary tract pathogens, the bacteria tested were consecutive clinical urinary tract isolates during a 45-day period from the laboratories of the Cleveland Clinic Foundation, Cleveland, Ohio, Kaiser Foundation Hospital, Portland, Oregon and Sacramento Medical Center, Sacramento, California (broth dilution), Northwestern Memorial Hospital, Chicago, Illinois, St. Francis Hospital, Wichita, Kansas, and St. Vincent Hospital \& Medical Center, Portland, Oregon (agar dilution). A total of 5,743 facultative and aerobic isolates were tested in this phase. Identification of these isolates was accomplished by the API system, replicator method ${ }^{11)}$ and conventional biochemical and serological procedures. Four common quality control organisms were tested daily by each laboratory: Escherichia coli (ATCC 25922), Staphylococcus aureus (ATCC 25923), Pseudomonas aeruginosa (ATCC 27853) and Streptococcus faecalis (ATCC 29212). Haemophilis vaginalis (25 strains), penicillin-susceptible Neisseria gonorrhoeae (50 strains), penicillin-resistant $N$. gonorrhoeae (52 strains) and $N$. meningitidis (70 strains) were selected from clinical isolates referred to the Center for Disease Control (CDC). The bacteria used in the studies on $\mathrm{pH}$ effect, inoculum size effect, bactericidal activity and disc diffusions regression analysis were clinical isolates submitted by the laboratories listed above. The latter studies were performed at CDC, Kaiser Foundation Laboratory and Sacramento Medical Center.

\section{Susceptibility Testing}

Minimal inhibitory concentrations (MIC's) and minimal lethal concentrations (MLC's) by broth microdilution were determined by methods previously described ${ }^{12}$. MIC's by agar dilution were measured using a Steer's replicator ${ }^{13)}$ as described previously ${ }^{14)}$. In testing the susceptibility of $H$. vaginalis, fetal calf serum was added to the MUELLER-HiNTON broth to a final concentration of $2 \%$, and was incubated at $35^{\circ} \mathrm{C}$ for $48 \sim 72$ hours. $N$. gonorrhoeae susceptibility testing was performed by agar dilution using proteose $\$ 3$ agar with $1 \%$ hemoglobin and $1 \%$ KeLLOGG's supplement.

In assessing the effect of $\mathrm{pH}$ on antimicrobic activity, antibiotic-containing MUELLER-HINTON broth was adjusted with phosphate buffers to pH's of 6.4, 7.4 and 8.4 and the bacteria were tested simultaneously at each $\mathrm{pH}$. In testing the effect of inoculum size on MIC's, bacterial inocula of $10^{3}$, 
$10^{5}$ and $10^{7}$ colony forming units (CFU's) were tested simultaneously. Disc diffusion susceptibility tests were performed by the method of BAUER, et al. ${ }^{15)}$ and modified by the NCCLS ${ }^{16)}$.

\section{Results}

\section{Minimal Inhibitory Concentration}

Table 1 summarizes the results of the susceptibilities of clinical urinary tract isolates from six

Table 1. MIC's of rosamicin (R), erythromycin (E) and ampicillin (A) against 5,545 urinary tract isolates.

\begin{tabular}{|c|c|c|c|c|c|c|c|c|c|}
\hline & \multirow{2}{*}{$\begin{array}{l}\text { No. of } \\
\text { isolates }\end{array}$} & & \multicolumn{7}{|c|}{ Cumulative $\%$ susceptibility at concentrations $(\mu \mathrm{g} / \mathrm{ml})$ of: } \\
\hline & & & 0.5 & 2 & 4 & 8 & 16 & 32 & 128 \\
\hline E. coli & 2590 & $\begin{array}{l}\mathrm{R} \\
\mathrm{E} \\
\mathrm{A}\end{array}$ & $\begin{array}{r}<1 \\
<1 \\
3\end{array}$ & $\begin{array}{r}2 \\
1 \\
41\end{array}$ & $\begin{array}{r}4 \\
1 \\
69\end{array}$ & $\begin{array}{r}27 \\
3 \\
76\end{array}$ & $\begin{array}{r}80 \\
6 \\
78\end{array}$ & $\begin{array}{l}95 \\
27 \\
81\end{array}$ & $\begin{array}{l}99 \\
95 \\
83\end{array}$ \\
\hline K. pneumoniae & 532 & $\begin{array}{l}\mathrm{R} \\
\mathrm{E} \\
\mathrm{A}\end{array}$ & $<1$ & $\begin{array}{l}<1 \\
<1\end{array}$ & $\begin{array}{r}<1 \\
<1 \\
1\end{array}$ & $\begin{array}{l}8 \\
3\end{array}$ & $\begin{array}{l}14 \\
17\end{array}$ & $\begin{array}{r}74 \\
6 \\
53\end{array}$ & $\begin{array}{l}98 \\
82 \\
81\end{array}$ \\
\hline E. cloacae & 92 & $\begin{array}{l}\mathrm{R} \\
\mathrm{E} \\
\mathrm{A}\end{array}$ & & & 1 & $\begin{array}{l}1 \\
9\end{array}$ & $\begin{array}{r}4 \\
28\end{array}$ & $\begin{array}{r}33 \\
1 \\
40\end{array}$ & $\begin{array}{r}100 \\
31 \\
53\end{array}$ \\
\hline S. marcescens & 89 & $\begin{array}{l}\mathrm{R} \\
\mathrm{E} \\
\mathrm{A}\end{array}$ & & & & 2 & $\begin{array}{r}12 \\
7\end{array}$ & $\begin{array}{l}65 \\
15\end{array}$ & $\begin{array}{l}97 \\
36 \\
36\end{array}$ \\
\hline P. mirabilis & 447 & $\begin{array}{l}\mathrm{R} \\
\mathrm{E} \\
\mathrm{A}\end{array}$ & $\begin{array}{l}<1 \\
<1 \\
16\end{array}$ & $\begin{array}{r}<1 \\
85\end{array}$ & $\begin{array}{r}<1 \\
89\end{array}$ & $\begin{array}{r}1 \\
<1 \\
90\end{array}$ & $\begin{array}{r}2 \\
1 \\
91\end{array}$ & $\begin{array}{r}15 \\
1 \\
92\end{array}$ & $\begin{array}{r}98 \\
7 \\
93\end{array}$ \\
\hline M. morganii & 57 & $\begin{array}{l}\mathrm{R} \\
\mathrm{E} \\
\mathrm{A}\end{array}$ & & 3 & 24 & & & $\begin{array}{l}16 \\
31\end{array}$ & $\begin{array}{l}97 \\
12 \\
60\end{array}$ \\
\hline $\begin{array}{l}\text { Other (11 species) } \\
\text { Enterobacteriaceae }\end{array}$ & 244 & $\begin{array}{l}\mathrm{R} \\
\mathrm{E} \\
\mathrm{A}\end{array}$ & $\begin{array}{r}<1 \\
2\end{array}$ & $\begin{array}{l}1 \\
5\end{array}$ & $\begin{array}{l}1 \\
7\end{array}$ & $\begin{array}{r}2 \\
18\end{array}$ & $\begin{array}{r}13 \\
1 \\
28\end{array}$ & $\begin{array}{r}48 \\
3 \\
46\end{array}$ & $\begin{array}{l}97 \\
41 \\
66\end{array}$ \\
\hline P. aeruginosa & 451 & $\begin{array}{l}\mathrm{R} \\
\mathrm{E} \\
\mathrm{A}\end{array}$ & $\begin{array}{l}<1 \\
<1\end{array}$ & $\begin{array}{l}<1 \\
<1 \\
<1\end{array}$ & $\begin{array}{l}1 \\
1\end{array}$ & $\begin{array}{l}2 \\
1 \\
1\end{array}$ & $\begin{array}{l}4 \\
2 \\
1\end{array}$ & $\begin{array}{r}11 \\
5 \\
2\end{array}$ & $\begin{array}{r}75 \\
22 \\
4\end{array}$ \\
\hline $\begin{array}{l}\text { Other ( } 5 \text { genera) } \\
\text { Nonfermenters }\end{array}$ & 62 & $\begin{array}{l}\mathrm{R} \\
\mathrm{E} \\
\mathrm{A}\end{array}$ & $\begin{array}{l}2 \\
2 \\
6\end{array}$ & $\begin{array}{l}5 \\
5\end{array}$ & $\begin{array}{l}8 \\
9\end{array}$ & $\begin{array}{l}20 \\
10 \\
19\end{array}$ & $\begin{array}{l}53 \\
31 \\
31\end{array}$ & $\begin{array}{l}68 \\
55 \\
48\end{array}$ & $\begin{array}{l}92 \\
78 \\
65\end{array}$ \\
\hline S. aureus & 360 & $\begin{array}{l}\mathrm{R} \\
\mathrm{E} \\
\mathrm{A}\end{array}$ & $\begin{array}{l}89 \\
89 \\
17\end{array}$ & $\begin{array}{l}97 \\
90 \\
45\end{array}$ & $\begin{array}{l}98 \\
48\end{array}$ & $\begin{array}{l}98 \\
92 \\
55\end{array}$ & $\begin{array}{l}99 \\
92 \\
66\end{array}$ & 76 & 93 \\
\hline S. epidermidis & 106 & $\begin{array}{l}\mathrm{R} \\
\mathrm{E} \\
\mathrm{A}\end{array}$ & $\begin{array}{l}76 \\
65 \\
54\end{array}$ & $\begin{array}{l}84 \\
73 \\
68\end{array}$ & $\begin{array}{l}86 \\
74 \\
69\end{array}$ & $\begin{array}{l}87 \\
81\end{array}$ & $\begin{array}{l}88 \\
75 \\
93\end{array}$ & $\begin{array}{l}78 \\
97\end{array}$ & $\begin{array}{l}83 \\
97\end{array}$ \\
\hline S. faecalis & 438 & $\begin{array}{l}\mathrm{R} \\
\mathrm{E} \\
\mathrm{A}\end{array}$ & $\begin{array}{l}38 \\
26 \\
20\end{array}$ & $\begin{array}{l}76 \\
73 \\
98\end{array}$ & $\begin{array}{r}78 \\
79 \\
100\end{array}$ & $\begin{array}{l}79 \\
80\end{array}$ & $\begin{array}{l}80 \\
80\end{array}$ & $\begin{array}{l}81 \\
81\end{array}$ & $\begin{array}{l}83 \\
82\end{array}$ \\
\hline $\begin{array}{l}\text { Other ( } 10 \text { species) } \\
\text { Gram-positive isolates }\end{array}$ & 77 & $\begin{array}{l}\mathrm{R} \\
\mathrm{E} \\
\mathrm{A}\end{array}$ & $\begin{array}{l}68 \\
69 \\
84\end{array}$ & $\begin{array}{l}77 \\
75 \\
95\end{array}$ & $\begin{array}{r}77 \\
100\end{array}$ & $\begin{array}{l}78 \\
79\end{array}$ & 80 & & $\begin{array}{l}81 \\
87\end{array}$ \\
\hline Total all isolates & 5,545 & $\begin{array}{l}\mathrm{R} \\
\mathrm{E} \\
\mathrm{A}\end{array}$ & $\begin{array}{r}11 \\
10 \\
5\end{array}$ & $\begin{array}{l}16 \\
14 \\
39\end{array}$ & $\begin{array}{l}17 \\
15 \\
56\end{array}$ & $\begin{array}{l}29 \\
16 \\
60\end{array}$ & $\begin{array}{l}56 \\
18 \\
64\end{array}$ & $\begin{array}{l}74 \\
30 \\
71\end{array}$ & $\begin{array}{l}96 \\
74 \\
77\end{array}$ \\
\hline
\end{tabular}


Table 2. MIC's of rosamicin (R), erythromycin (E), ampicillin (A), penicillin-G (P), tetracycline (T), cefoxitin (C), spectinomycin (S), minocycline (M), and rifampin (Ri) against H. vaginalis, N. gonorrhoeae and N. meningitidis.

\begin{tabular}{|c|c|c|c|c|c|c|c|c|c|c|c|c|c|c|c|}
\hline \multirow{2}{*}{$\begin{array}{c}\text { Organism } \\
\text { drug }\end{array}$} & & \multicolumn{14}{|c|}{ Cumulative $\%$ susceptible at concentrations $(\mu \mathrm{g} / \mathrm{ml})$ of: } \\
\hline & & 0.015 & 0.03 & 0.06 & 0.12 & 0.25 & 0.5 & 1.0 & 2.0 & 4.0 & 8.0 & 16 & 32 & 64 & 128 \\
\hline H. vaginalis* $(25)$ & $\begin{array}{l}\mathrm{R} \\
\mathrm{E} \\
\mathrm{A} \\
\mathrm{P} \\
\mathrm{T}\end{array}$ & & & & $\begin{array}{l}68 \\
88 \\
68 \\
88\end{array}$ & $\begin{array}{l}92 \\
96 \\
84 \\
96\end{array}$ & $\begin{array}{r}100 \\
96 \\
100 \\
16\end{array}$ & $\begin{array}{r}100 \\
24\end{array}$ & 100 & & & 28 & 40 & 96 & 100 \\
\hline $\begin{array}{l}\text { N. gonorrhoeae** } \\
(50) \\
\text { (P-susceptible) }\end{array}$ & $\begin{array}{l}R \\
E \\
P \\
T \\
C \\
S\end{array}$ & $\begin{array}{r}4 \\
32\end{array}$ & $\begin{array}{r}2 \\
36\end{array}$ & $\begin{array}{r}32 \\
4 \\
56\end{array}$ & $\begin{array}{r}90 \\
26 \\
70 \\
4 \\
32\end{array}$ & $\begin{array}{r}100 \\
70 \\
80 \\
42 \\
66\end{array}$ & $\begin{array}{l}90 \\
98 \\
72 \\
80\end{array}$ & $\begin{array}{r}96 \\
100 \\
92 \\
98\end{array}$ & $\begin{array}{l}100 \\
100 \\
100\end{array}$ & & 2 & 98 & & & \\
\hline $\begin{array}{l}\text { N. gonorrhoeae }{ }^{* *} \\
\text { (52) } \\
\text { (P-resistant) }\end{array}$ & $\begin{array}{l}\mathrm{R} \\
\mathrm{E} \\
\mathrm{P} \\
\mathrm{T} \\
\mathrm{C} \\
\mathrm{S}\end{array}$ & $\begin{array}{r}12 \\
2\end{array}$ & $\begin{array}{l}18 \\
12\end{array}$ & $\begin{array}{l}28 \\
18\end{array}$ & $\begin{array}{l}73 \\
38\end{array}$ & 98 & $\begin{array}{r}100 \\
54 \\
\\
18 \\
34\end{array}$ & $\begin{array}{r}80 \\
2 \\
44 \\
72\end{array}$ & $\begin{array}{r}100 \\
6 \\
82 \\
98\end{array}$ & $\begin{array}{r}16 \\
100 \\
100\end{array}$ & & 100 & & & \\
\hline $\begin{array}{l}\text { N. meningitidis** } \\
(70)\end{array}$ & $\begin{array}{l}\mathrm{R} \\
\mathrm{E} \\
\mathrm{P} \\
\mathrm{M} \\
\mathrm{Ri}\end{array}$ & $\begin{array}{r}3 \\
7 \\
31\end{array}$ & $\begin{array}{l}16 \\
71 \\
62\end{array}$ & $\begin{array}{r}83 \\
3 \\
97 \\
83\end{array}$ & $\begin{array}{l}96 \\
99 \\
89\end{array}$ & $\begin{array}{l}99 \\
13 \\
96\end{array}$ & $\begin{array}{r}100 \\
70 \\
\\
99\end{array}$ & $\begin{array}{r}97 \\
100 \\
49 \\
100\end{array}$ & $\begin{array}{r}99 \\
100\end{array}$ & 100 & & & & & \\
\hline
\end{tabular}

* Range of drug concentrations tested: $0.12 \sim 128 \mu \mathrm{g} / \mathrm{ml}$

** Range of drug concentrations tested: $0.015 \sim 16 \mu \mathrm{g} / \mathrm{ml}$

laboratories to rosamicin, erythromycin and ampicillin. Although the isolates tested by agar dilution and broth dilution were slightly different, the mean MIC's for each species were almost invariably within one dilution of each other. Consequently, the results of both methods are summarized as one in Table 1. Against Gram-negative isolates, ampicillin showed greater activity than the two macrolides, and rosamicin was more active than erythromycin. Against Gram-positive isolates no significant difference in activity was observed between rosamicin and erythromycin. Both drugs were more active than ampicillin against Gram-positive bacteria other than enterococci. At $2 \mu \mathrm{g} / \mathrm{ml}$, less than $5 \%$ of Gram-negative isolates were susceptible to rosamicin, but greater than $80 \%$ of Gram-positive bacteria were susceptible.

The genital pathogens $N$. gonorrhoeae and $H$. vaginalis were found to be highly susceptible to rosamicin, as summarized in Table 2. One hundred percent of penicillin-susceptible N. gonorrhoeae, $98 \%$ of penicillinase-producing gonococci and $92 \%$ of $H$. vaginalis were inhibited by $0.25 \mu \mathrm{g} / \mathrm{ml}$ of rosamicin. Rosamicin was significantly more active than erythromycin against gonococci, but no difference between the two drugs was observed against $H$. vaginalis.

\section{$\mathrm{pH}$ and Inoculum Size Effect}

The effect of $\mathrm{pH}$ on the activity of rosamicin was minimal with Gram-positive bacteria, but a two to fourfold increase in activity was observed with Gram-negative bacteria when increasing the $\mathrm{pH}$ from 6.4 to 8.4 (Fig. 1). A similar effect was observed with erythromycin.

Inoculum size had a marked effect on both rosamicin and erythromycin MIC's, particularly 
Fig. 1. Effect of $\mathrm{pH}$ on susceptibility of representative bacteria to rosamicin.

Bacterial MIC's shown are: Strep. pneumoniae, Staph. aureus, E. coli, K. pneumoniae, S. marcescens, P. mirabilis, Aeromonas, P. aeruginosa, and A. calcoaceticus var. anitratus. Numbers in parentheses are numbers of isolates tested.

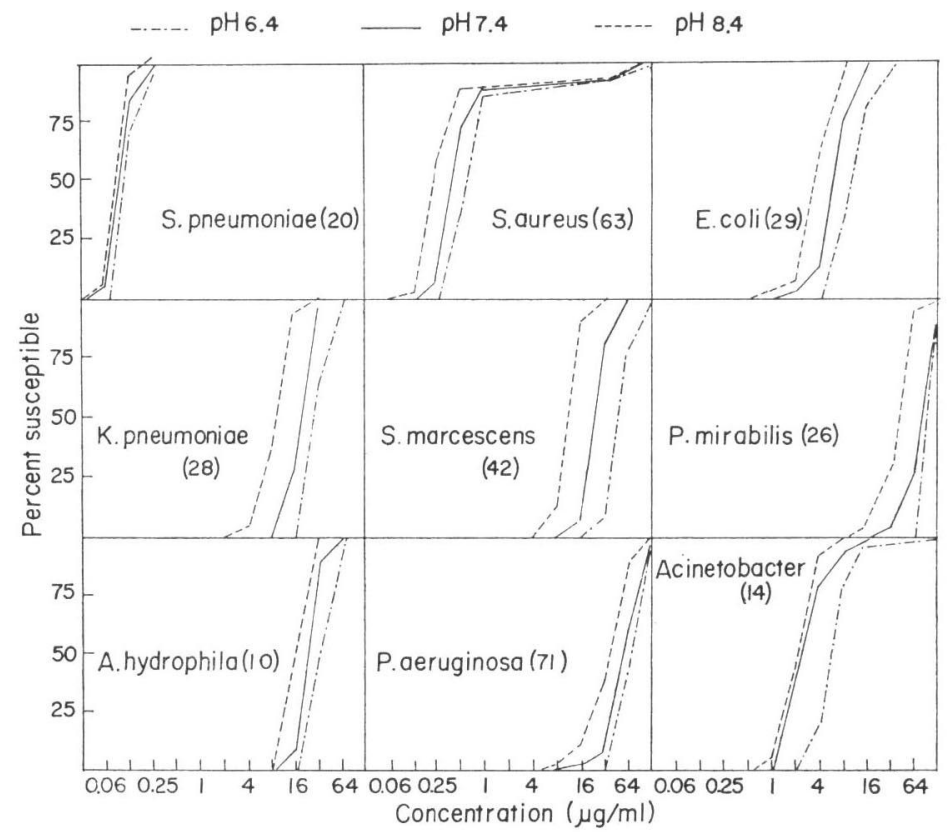

when increasing the inoculum from $10^{5}$ to $10^{7}$ CFU/ml (Fig. 2). The difference in MIC's were usually greater than fourfold when inoculum size was increased from $10^{5}$ to $10^{7} \mathrm{CFU} / \mathrm{ml}$, but between inocula of $10^{3}$ and $10^{5} \mathrm{CFU} / \mathrm{ml}$ the MIC differences were often negligible or non-existent.

\section{Minimal Lethal Concentrations}

The difference between MIC's and MLC'S of rosamicin and erythromycin with most organisms was not striking. For many organisms this could not be assessed adequately because the MIC's were already at the highest concentration tested. Ten Serratia marcescens strains, for example, were all inhibited by $32 \mu \mathrm{g} / \mathrm{ml}$ of rosamicin, but only $40 \%$ were killed by $64 \mu \mathrm{g} / \mathrm{ml}$ (Fig. 3). For 10 strains of Staphylococcus aureus, however, $100 \%$ were both inhibited and killed by $1 \mu \mathrm{g} / \mathrm{ml}$ of rosamicin (Fig. 3).
Fig. 2. Effect of inoculum sizes of $10^{7}, 10^{5}$ and $10^{3}$ $\mathrm{CFU} / \mathrm{ml}$ on susceptibility of 10 strains each of Staph. aureus, Staph. epidermidis, E. coli, and S. marcescens to rosamicin.

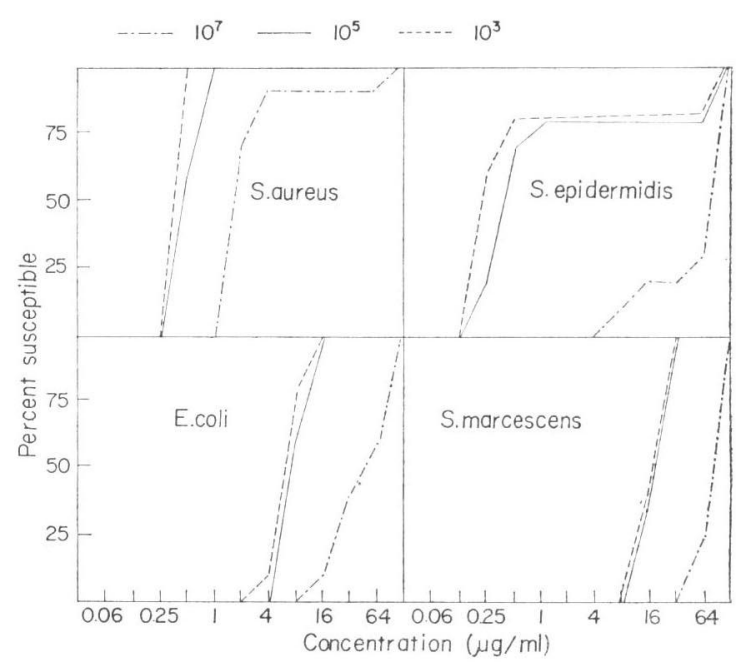

Broth Microdilution/Disc Diffusion Comparison

The comparative endpoint distribution of rosamicin and erythromycin disc diffusion zone sizes 
Fig. 3. MIC and MLC of rosamicin against Staph. epidermidis and Serratia marcescens at $\mathrm{pH} 7.4$ with $10^{5} \mathrm{CFU} / \mathrm{ml}$ inoculum.

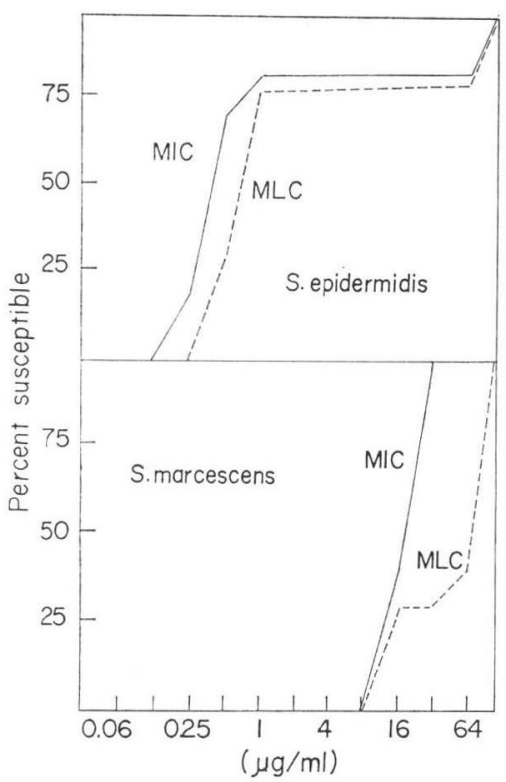

Fig. 4. Regression curves for rosamicin and erythromycin.

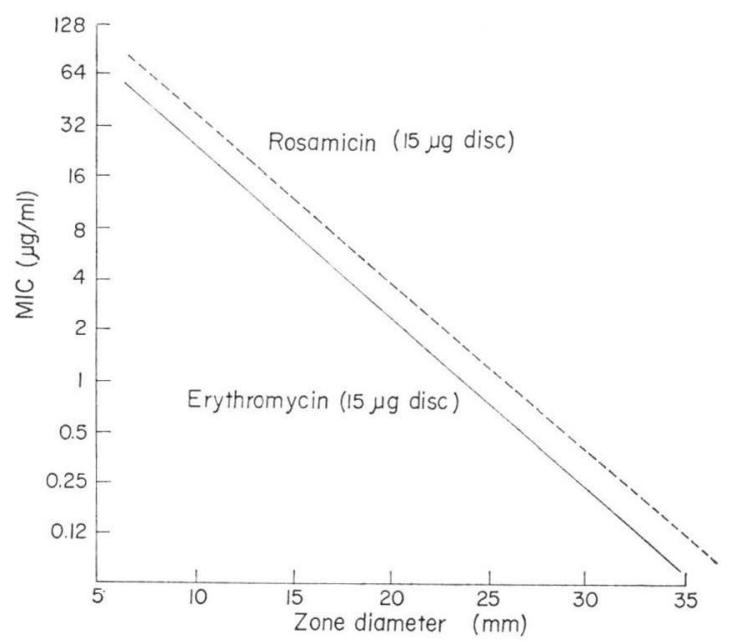

and broth microdilution MIC's at $\mathrm{pH} 7.4$ is displayed in Fig. 4. The correlation coefficient for the rosamicin analysis was 0.93 and that for the erythromycin was 0.97 . The y intercepts ex-

pressed in $\log _{2}$ scale were 12.7 and 11.9 for rosamicin and erythromycin respectively.

\section{Discussion}

The following results of the current study confirm those of previous reports on rosamicin: (1) The in vitro activity of rosamicin did not differ significantly from that of erythromycin against $S$. aureus $^{1,6)}$; (2) Erythromycin in vitro activity was greater than that of rosamicin against S. pyogenes ${ }^{17}$; (3) The in vitro activity of rosamicin was superior to that of erythromycin against Enterobacteriaceae ${ }^{1,2)}$, and non-fermentative Gram-negative bacilli $\left.{ }^{2}, 6\right)$; (4) The effect of increasing $\mathrm{pH}$ on enhanced in vitro activity of rosamicin ${ }^{1,2)}$ was comparable to that of erythromycin ${ }^{18,19}$.

The effect of inoculum size was significant with inocula 2 logs above $10^{5} \mathrm{CFU} / \mathrm{ml}$, but was minimal with inocula 2 logs below this concentration. Consequently, inocula greater than the standard $10^{5}$ $\mathrm{CFU} / \mathrm{ml}$ may result in false high MIC's with both rosamicin and erythromycin. The MLC'S of both drugs were only slightly increased over the MIC's against Gram-positive isolates, but a much greater difference between these two values was observed with Gram-negative isolates. It appears, therefore, that rosamicin may have significant bactericidal activity against Gram-positive isolates.

Regression line analysis of rosamicin, using the $15-\mu \mathrm{g}$ disc showed a clear breakpoint at $24 \mathrm{~mm}$ zone size. Organisms with rosamicin MIC's of $1 \mu \mathrm{g} / \mathrm{ml}$ or less had zones of inhibition of $24 \mathrm{~mm}$ or greater, whereas those with rosamicin MIC's of $2 \mu \mathrm{g} / \mathrm{ml}$ or greater had zones of less than 24 . A susceptible level of $1 \mu \mathrm{g} / \mathrm{ml}$ would be reasonable for genital isolates, since this level is readily achieved in the prostate, urethra and vaginal secretions. But such a breakpoint would be completely inappropriate for achievable serum levels. For levels below $1 \mu \mathrm{g} / \mathrm{ml}$ our data showed no zone size differentials with the $15-\mu \mathrm{g}$ disc. Using the $24 \mathrm{~mm}$ zone breakpoint for the 280 on-scale bacteria tested, there were two very major discrepancies ( 2 isolates with rosamicin MIC of $2 \mu \mathrm{g} / \mathrm{ml}$ had zone sizes of 25 and $26 \mathrm{~mm}$ ) and no major discrepancies.

We were unable to adequately assess the current NCCLS zone size criteria for erythromycin because there were only 2 isolates in our series inhibited by $2 \mu \mathrm{g} / \mathrm{ml}$ of erythromycin - the current NCCLS susceptibility breakpoint for MIC's. For isolates with MIC's of $1 \mu \mathrm{g} / \mathrm{ml}$ or less, there were no discrep- 
ancies with the NCCLS zone size criterion of $>18 \mathrm{~mm}$. But there were numerous discrepancies with organisms inhibited by $4 \mu \mathrm{g} / \mathrm{ml}$ ( 6 minor and 1 very major), $8 \mu \mathrm{g} / \mathrm{ml}$ ( 6 minor and 3 very major) and $16 \mu \mathrm{g} / \mathrm{ml}$ (3 minor and 1 very major). Thus, of 48 isolates inhibited by 4 to $16 \mu \mathrm{g} / \mathrm{ml}$ of erythromycin there were $15(31 \%)$ minor and $5(10 \%)$ very major discrepancies. In our hands, the current NCCLS zone size breakpoints for erythromycin were not appropriate, but because of the scarcity of isolates inhibited by 1 and $2 \mu \mathrm{g} / \mathrm{ml}$ of erythromycin, we are unable to suggest improved breakpoints at this time.

Cross susceptibility and resistance between rosamicin and erythromycin was almost $100 \%$ when susceptibility breakpoints of $0.5 \mu \mathrm{g} / \mathrm{ml}$ (or $0.1 \mu \mathrm{g} / \mathrm{ml}$ ) for rosamicin and $2 \mu \mathrm{g} / \mathrm{ml}$ for erythromycin were used. Of all isolates we studied, only 2 strains of $H$. vaginalis showed discrepancies - both being susceptible to erythromycin (MIC's- $0.25 \mu \mathrm{g} / \mathrm{ml}$ ) and resistant to rosamicin (MIC's-2.0 $\mu \mathrm{g} / \mathrm{ml}$ ). Discrepancies between the erythromycin and rosamicin $15 \mu \mathrm{g}$ disc zone sizes reflected identically the discrepancies between the erythromycin zone sizes and MIC's discussed above. It appears that either drug may be tested alone as a representative of both macrolides when utilizing dilution methods, but revised zone size criteria must be established before recommending the same for the disc diffusion method.

Rosamicin demonstrated good in vitro activity against $N$. meningitidis-comparable to that of rifampin. Ninety-six percent of isolates were inhibited by $0.12 \mu \mathrm{g} / \mathrm{ml}$. Its potential role in the treatment of meningococcal pharyngeal carriers, however, remains speculative since rosamicin levels in the pharynx have not been reported to date.

The published pharmacokinetic studies to date on rosamicin are relatively sparse ${ }^{9,10)}$, but a reasonable peak serum level after ingestion of a $250-\mathrm{mg}$ dose appears to be $0.5 \mu \mathrm{g} / \mathrm{ml}$. Since only about $10 \%$ of all clinical urinary tract isolates in this study were inhibited by this level of rosamicin, it would appear that this drug offers little promise in the treatment of systemic Gram-negative or upper urinary tract infections. Assuming a peak urine concentration of $16 \mu \mathrm{g} / \mathrm{ml}$ of rosamicin $(30 \times$ peak serum levels), $80 \%$ of E. coli, but only $54 \%$ of all Enterobacteriaceae isolates in this study would have been inhibited by this level at a $\mathrm{pH}$ of 7.4. Even by further alkalinizing the urine to a $\mathrm{pH}$ of 8.4, which would essentially halve the MIC's, the urine levels would not reach the $5 \sim 10$ times the MIC generally recommended for urinary tract infections. In view of the many currently effective urinary tract antimicrobics, we find little to support further studies for this drug in the area of urinary tract infections.

In the arena of genital infections, rosamicin offers considerable promise. First, the drug is selectively concentrated in the prostate, urethral and vaginal secretions - up to thirty times serum levels ${ }^{9,10)}$. Secondly, the major genital pathogens are extremely susceptible to rosamicin. In previous reports ${ }^{5,8}$, as well as the current study, $100 \%$ of both beta-lactamase positive and negative $N$. gonorrhoeae were susceptible to rosamicin at levels of $0.5 \mu \mathrm{g} / \mathrm{ml}$ or less. Ninety-two percent of $H$. vaginalis strains were susceptible to $0.25 \mu \mathrm{g} / \mathrm{ml}$ of rosamicin, with two strains requiring $2.0 \mu \mathrm{g} / \mathrm{ml}$. One hundred percent of thirty clinical isolates of Chlamydia trachomatis were inhibited by $0.1 \mu \mathrm{g} / \mathrm{ml}$ of rosamicin ${ }^{7}$. In view of these data we conclude that rosamicin merits clinical investigation in the treatment of gonococcal genital infections as well as non-gonococcal urethritis.

\section{References}

1) Waitz, J. A.; C. G. Drube, E. L. Moss, Jr. \& J. J. Weinstein: Biological studies with rosamicin, a new Micromonospora-produced macrolide antibiotic. J. Antibiotics 25: 647 652, 1972

2) Crow, C. C. \& W. E. SAnders, Jr.: Rosamicin: Evaluation in vitro and comparison with erythromycin and lincomycin. Antimicr. Agents \& Chemoth. 5: 272 275, 1974

3) Sutter, V. L. \& S. M. Finegold: Rosamicin: In vitro activity against anaerobes and comparison with erythromycin. Antimicr. Agents \& Chemoth. 9: 350 351, 1976

4) Shadomy, S.; M. Tipple \& L. Paxton: Josamycin and rosamicin: In vitro comparisons with erythromycin and clindamycin. Antimicr. Agents \& Chemoth. 10: 773 775, 1976

5) Sanders, C. C. \& W. E. Sanders, Jr.: In vitro activity of rosamicin against Neisseria and Haemophilus, including penicillinase-producing strains. Antimicr. Agents \& Chemoth. 12: 293 294, 1977

6) DiPersio, J. R. \& T. L. KrafczyK: In vitro activity of rosamicin and erythromycin against a group of 
nonfermenting Gram-negative bacilli. Antimicr. Agents \& Chemoth. 14: 274 276, 1978

7) Sмith, T. F. \& H. E. Washton: In vitro susceptibility of 30 strains of Chlamydia trachomatis to rosamicin. Antimicr. Agents \& Chemoth. 14: 493 494, 1978

8) Biddle, J. W. \& C. Thornsberry: In vitro activity of rosamicin, josamycin, erythromycin, and clindamycin against $\beta$-lactamase-negative and $\beta$-lactamase-positive strains of Neisseria gonorrhoeae. Antimicr. Agents \& Chemoth. 15: 243 245, 1979

9) Hoyme, U.; A. Baumueller \& P. O. Madsen: Rosamicin in urethral and vaginal secretions and tissues in dogs and rats. Antimicr. Agents \& Chemoth. 12: 237 239, 1977

10) Baumueller, A.; U. Hoyme \& P. O. Madsen: Rosamicin-a new drug for the treatment of bacterial prostatitis. Antimicr. Agents \& Chemoth. 12: 240 242, 1977

11) Fuchs, P. D.: The replicator method for identification and biotyping of common bacterial isolates. Lab. Med. 6 (No. 5): $6 \sim 11,1975$

12) Fuchs, P. C.; C. Thornsberry, A. L. Barry, T. L. Gavan, E. H. Gerlach \& R. N. Jones: Ticarcillin, carbenicillin and BL-P1908: In vitro comparison of three anti-pseudomonal semisynthetic penicillins. J. Antibiotics 30: 1098 1106, 1977

13) Steers, E.; E. L. Foltz \& B. S. Graves: An inocula replicating apparatus for routine testing of bacterial susceptibility to antibiotics. Antibiot. \& Chemoth. 9: 307 311, 1959

14) Jones, R. N.; A. L. Barry, P. C. Fuchs, T. L. Gavan, E. H. Gerlach, H. Sommers \& C. Thornsberry: 1-N-(S-3-Amino-2-hydroxypropionyl) gentamicin B (Sch 21420): A collaborative in vitro susceptibility comparison with amikacin and gentamicin against 12,984 clinical isolates. Current Microbiol. 1: 359 364, 1978

15) Bauer, A. W.; W. M. M. Kirby, J. C. Sherris \& M. Turck: Antibiotic susceptibility testing by a standardized single disk method. Am. J. Clin. Path. 45: 493 496, 1966

16) NCCLS Subcommittee on Antimicrobial Susceptibility Tests: Performance standards for antimicrobial disc susceptibility tests. National Committee for Clinical Laboratory Standards. Villanova, PA, 1975

17) Saroglou, G. \& A. L. Bisno: Susceptibility of skin and throat strains of group A streptococci to rosamicin and erythromycin. Antimicr. Agents \& Chemoth. 13: 701 702, 1978

18) Sabath, L. D.; V. Lorian, D. Gerstein, P. B. Loder \& M. Finland: Enhancing effect on alkalinization of the medium on the activity of erythromycin against Gram-negative bacteria. Appl. Microbiol. 16: 1288 1292,1968

19) Lorian, V. \& L. D. SABAth: Effect of $\mathrm{pH}$ on the activity of erythromycin against 500 isolates of Gramnegative bacilli. Appl. Microbiol. 20: 754 756, 1970 